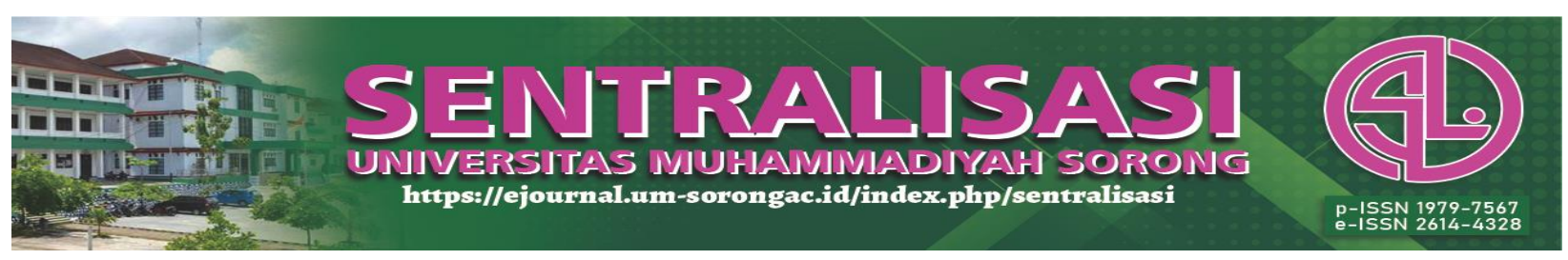

\title{
The Comparative Analysis Of Employee Performance Before And After The Provision Of Remuneration At The Ministry Of Religion In North Gorontalo District
}

\author{
Yakup $^{1}$, Sasmita R. Setiawan ${ }^{2}$, Fatra Biyangi ${ }^{3}$ \\ 1,2,3 Fakultas Ekonomi Universitas Gorontalo, Indonesia \\ E-mail : $\underline{\text { akup.ug@gmail.com }}$
}

direvisi: 05/01/2021 dipublikasikan: 31/01/2021

\begin{abstract}
Abstrak. Tujuan dari penelitian ini adalah untuk menguji dan menganalisis perbedaan kinerja sebelum dan sesudah Pemberian Remunerasi Pegawai di Kementerian Agama Kabupaten Gorontalo Utara. Data yang dipergunakan dalam penelitian ini adalah data primer yang berumber dari responden melalui pengisian daftar kuisioner. Populasi penelitian berjumlah 82 orang pegawai dengan menggunakan metode sensus. Metode analisis yang digunakan untuk menjawab masalah penelitian dan menguji hipotesis adalah Analysis of variance (ANOVA) menggunakan aplikasi Statistical Product Service Solution (SPSS). Hasil penelitian diperoleh nilai F-hitung skor kinerja sebelum remunerasi $=2,676$ dengan nilai signifikansi $=0,006$. Sedangkan F-hitung skor kinerja setelah remunerasi $=3,193$ dengan nilai signifikansi $=0,001$, dari hasil uji ini menunjukkan terdapat perbedaan yang signifikan kinerja sebelum dan sesudah program remunerasi atau tunjangan kinerja, yaitu adanya peningkatan kinerja. Peningkatan kinerja pegawai setelah adanya remunerasi meliputi meningkatan kualitas kerja, kuantitas kerja, kehandalan, percepatan waktu kerja, penghematan biaya, kualitas pelayanan, integritas, komitmen kerja, peningkatan kedisiplinan, dan kerja sama.
\end{abstract}

Kata kunci: Perbedaan Kinerja, Pemberian Remunerasi, Pegawai

\begin{abstract}
This study aims to examine and analyze differences in employees' performance at the Ministry of Religion, North Gorontalo District, before and after the provision of remuneration. Primary data sources from questionnaires filled out by respondents. The study population consisted of 82 employees determined using the census method. The method employed to answer research problems and test hypotheses are the Analysis of Variance (ANOVA) with the application of Statistical Product Service Solution (SPSS). The results showed that the F-count of the performance score before the provision of remuneration was 2.676 with a significance value of 0.006, while the F-count of the performance score after the provision of remuneration was 3.193 with a significance value of 0.001 . These test results indicate a significant increase in performance after the provision of remuneration or performance allowances. Employee performance improvement includes the quality and quantity of work, reliability, accelerated working time, cost savings, quality of service, integrity, work commitment, discipline, and cooperation.
\end{abstract}

Keywords: Differences in Performance, Remuneration, Employees

\section{Introduction}

One of the government's attention to improving employee welfare is manifested in the provision of performance compensation such as remuneration as part of efforts to improve employee performance achievements. The remuneration policy is a service fee applied to all employees according to their grading or position and performance achievements. Remuneration is crucial in encouraging every employee to be more active in carrying out tasks according to organizational expectations. 


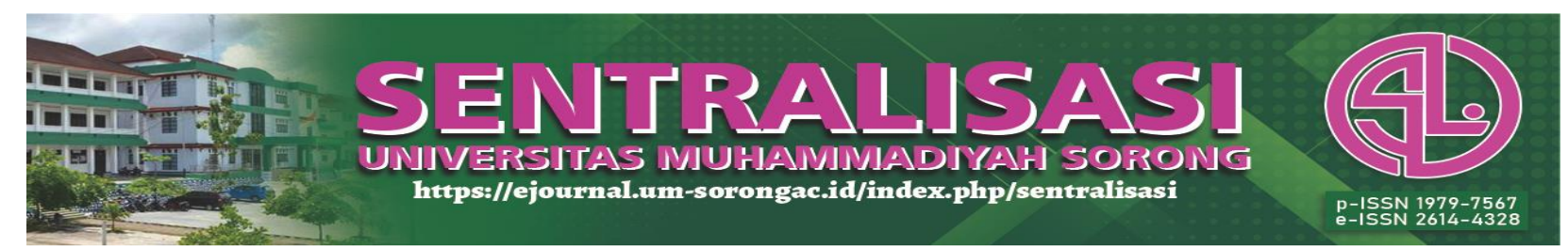

Rivai (in Saleh \& Darwis, 2015) explained that performance is the accumulation of work results achieved in various work activities and refers to implementing an assigned job. The activities refer to each field's primary duties based on employees' placement and position in the organization. The success of employees in carrying out their duties can be achieved by applying predetermined work standards and targets based on mutually agreed criteria. In line with this opinion, Mangkunegara (in Usmiar, 2016) argues that performance or work performance results from work as a whole, both the quality and quantity achieved by employees in carrying out their work according to their assigned duties and responsibilities.

Work performance is an amalgamation of three main components: individual abilities and interests, acceptance of descriptions in delegating task implementation, and individual support and motivation. The performance of employees expected by the organization is often not as planned, such as the lack of exemplary service to the community. Various inhibiting factors stem from the low level of employee welfare.

To increase the fulfillment of community needs, the Central Government has made efforts to improve services directly related to the community. They first improve employees' welfare through the provision of performance allowances (TUKIN) or better known as remuneration. This policy is regulated in the Presidential Regulation of the Republic of Indonesia Number 104 of 2014 concerning Employee Performance Benefits within the Ministry of Administrative Reform and Bureaucratic Reform. This policy attempts to encourage employees to increase their work motivation to no more prolonged use the excuse of insufficient salary not to carry out their duties properly.

Rivai and Sagala (in Karim, 2019) describe a performance allowance as a direct reward paid to employees for their performance that exceeds the specified standards. This system is a permanent compensation based on performance (pay for performance plan). The provision of remuneration, both financial and non-financial, is intended as an award or remuneration for employees to sacrifice their time, energy, and thoughts in carrying out their duties responsibly for the organization's progress.

The Ministry of Religion of North Gorontalo, as one of the government agencies, is in charge of the service, counseling, and guidance for religious life. In detail, this institution is tasked with carrying out Hajj and Umrah guidance, madrasa education, organizing religious education and religious harmony, and formulating technical policies in the implementation of administration and information. Besides, it is also responsible for implementing program planning coordination, control, implementation of monitoring, and evaluation and coordination with local governments, related agencies, and community institutions in the implementation of ministerial tasks. Before the remuneration program was issued, the community often complained of various problems, including the slow and uncertainty of Hajj departures, the inadequate development of madrasah education, and the frequent delay in administrative services for various reasons. 


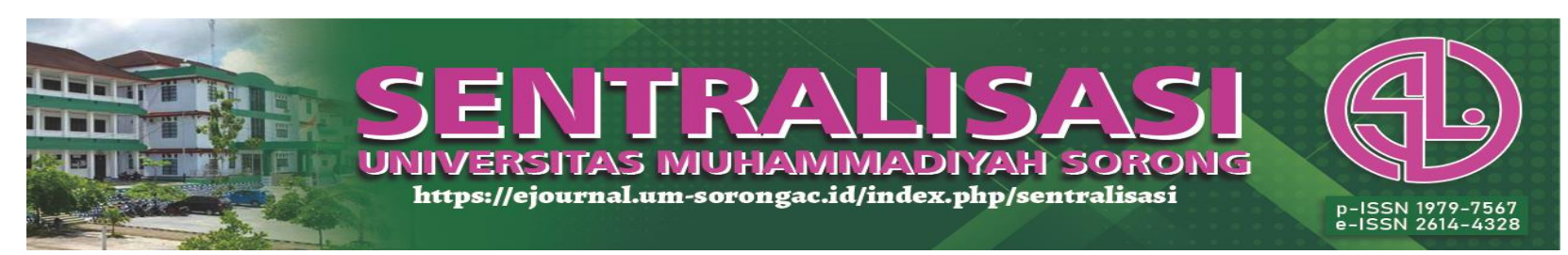

These problems are caused by the lack of seriousness of employees in carrying out their duties. This condition has been going on for years. For example, there are often delays and inadequate performance of the teaching staff at madrasah because their income is insufficient to meet family needs. Based on these problems and to improve services to the community, the government issued a policy to improve employee welfare through remuneration.

The remuneration program is expected to provide positive results in improving employee performance. Teja (2017) states that a remuneration is a form of implementing remuneration programs or rewards that individuals receive for their work achievements. It is expected that remuneration can change the work environment and attitudes of employees to be more motivated. Providing performance allowances to employees based on their ability, workload, and performance will provide a strong impetus for employee performance and organizational performance. Several research results prove that performance allowances or remuneration can improve performance (Hardani, Bachri, \& Dahniar, 2016), (Saleh \& Darwis, 2015). The same research findings (Nasution, Sudiarti, \& Harahap, 2019) also explain that performance allowances positively improve employee performance.

The data used in measuring the difference in employee performance are data before implementing the remuneration program for three years (2014-2016), while the comparative data are data after the implementation of the remuneration program for three years (2017-2019).

\section{Research Method}

This study employs a comparative quantitative method by comparing employees' performance before and after the implementation of the remuneration program. Data were obtained by distributing questionnaires to respondents. The data analysis used is a statistical analysis of variance (ANOVA) method, the OneWay ANOVA procedure. ANOVA analysis test is a model of testing the variability of data differences in each group's observations and the variability between group means. Through both variabilities, the average conclusion of the study population can be drawn.

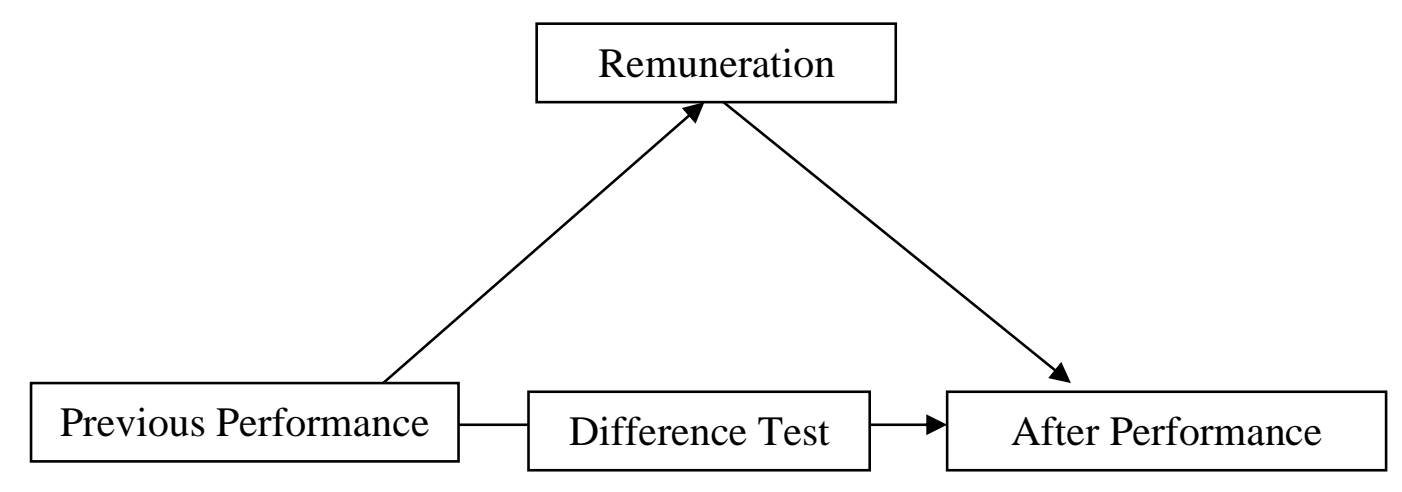

Image 1. Performance Difference Test Framework 


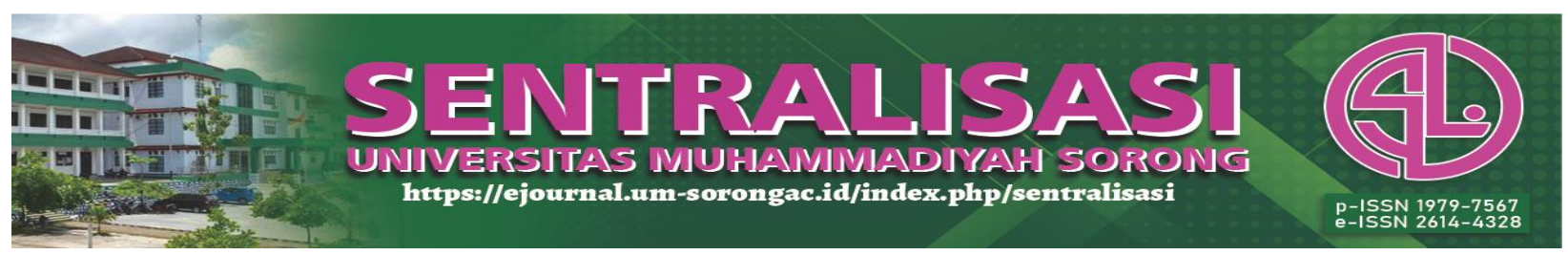

\section{Result and Discussion}

\section{Remuneration}

Table 1. Remuneration Validity Test Results

\begin{tabular}{cccc}
\hline $\begin{array}{c}\text { Item } \\
\text { Number }\end{array}$ & $\mathrm{R}_{\text {table }}$ & $\mathrm{R}_{\text {count }}$ & Information \\
\hline 1 & 0.367 & 0.570 & Valid \\
2 & 0.367 & 0.401 & Valid \\
3 & 0.367 & 0.658 & Valid \\
4 & 0.367 & 0.439 & Valid \\
5 & 0.367 & 0.570 & Valid \\
6 & 0.367 & 0.522 & Valid \\
7 & 0.367 & 0.428 & Valid \\
8 & 0.367 & 0.456 & Valid \\
9 & 0.367 & 0.397 & Valid \\
10 & 0,367 & 0,397 & Valid \\
\hline
\end{tabular}

Source: Results of processed data

The remuneration variable's measurement results showed that the value of $r$-count $>r$-table with a score of 0.367 at the $5 \%$ significance level. Thus, all statement items on the remuneration variable are declared valid.

\section{Performance}

Table 2. Performance Validity Test Results

\begin{tabular}{cccc}
\hline $\begin{array}{c}\text { Item } \\
\text { Number }\end{array}$ & $\mathrm{R}_{\text {table }}$ & $\mathrm{R}_{\text {count }}$ & Information \\
\hline 1 & 0.367 & 0.427 & Valid \\
2 & 0.367 & 0.481 & Valid \\
3 & 0.367 & 0.513 & Valid \\
4 & 0.367 & 0.410 & Valid \\
5 & 0.367 & 0.460 & Valid \\
6 & 0.367 & 0.562 & Valid \\
7 & 0.367 & 0.373 & Valid \\
8 & 0.367 & 0.460 & Valid \\
9 & 0.367 & 0.466 & Valid \\
10 & 0.367 & 0.398 & Valid \\
\hline
\end{tabular}

Source: Results of processed data

The performance variable measurement resulted in an r-count > r-table with a score of 0.367 at a significance level of $5 \%$. Thus, all questionnaire items on the performance variables are declared valid and feasible as an instrument to measure the research variables.

\section{Reliability Test}

The reliability test employed to determine the variable measuring instrument's consistency was the Cronbach's alpha method. The generally accepted standard of questionnaire items is that Cronbach's alpha values above 0.60 are declared reliable. Data processing shows the following results: 


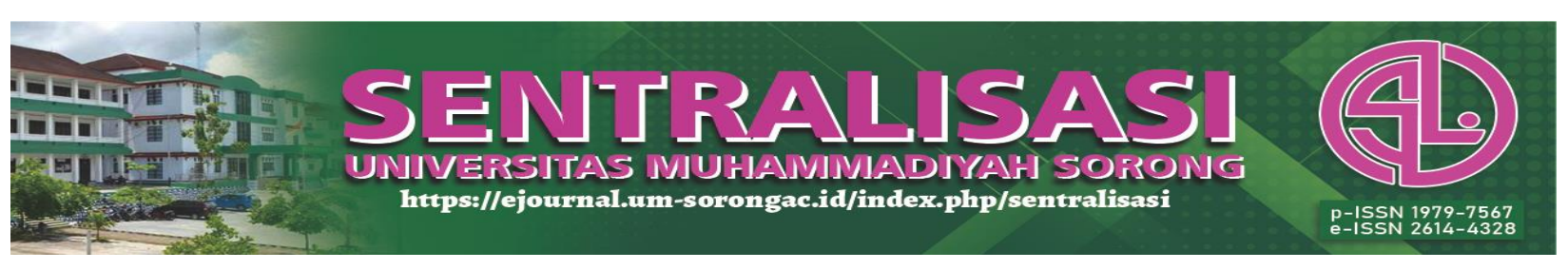

Table 3. Reliability Test Results

\begin{tabular}{lccc}
\hline \multicolumn{1}{c}{ Variable } & Alpa Value & Test Results & Information \\
\hline Remuneration & 0.60 & 0.806 & Reliable \\
Performance & 0.60 & 0.786 & Reliable \\
\hline
\end{tabular}

\section{Source: Results of processed data}

The test results show that Cronbach's alpha value on the research variable is more significant than 0.60 . Thus, the variables of remuneration and performance have high reliability.

\section{Test of Homogeneity of Variances}

The homogeneity of variances is a test of the variance of data groups on each variable, which is data before and after the provision of remuneration. The analysis results are presented in the following table.

Table 4. Test of Homogeneity of Variances

\begin{tabular}{lcccc}
\hline \multicolumn{4}{c}{ Test of Homogeneity of Variances } & \\
\hline & Levene Statistic & $\mathrm{df1}$ & $\mathrm{df} 2$ & Sig. \\
\hline $\begin{array}{l}\text { Performance before } \\
\text { remuneration }\end{array}$ & $.825^{\mathrm{a}}$ & 8 & 70 & .584 \\
$\begin{array}{l}\text { Performance after } \\
\text { remuneration }\end{array}$ & $1.716^{\mathrm{b}}$ & 8 & 70 & .110 \\
\hline
\end{tabular}

a. Groups with only one case are ignored in computing the homogeneity of variance for performance before remuneration.

b. Groups with only one case are ignored in computing the homogeneity of variance for performance after remuneration.

Source: Results of processed data

ANOVA testing assumes that the data group in the research variable gets the same or homogeneous results. The decision to implement the homogeneity test is if the significance score is $<0.05$, the variants of the research data group are different; conversely if the significance score was $>0.05$, the variants of the data groups were the same. The analysis on the output table obtained a significance value greater than 0.05 (0.584 and 0.110). Therefore, it can be decided that the two data groups before and after the provision of remuneration are the same. Thus, these results have met the basic assumptions of the Test of Homogeneity of Variances. 


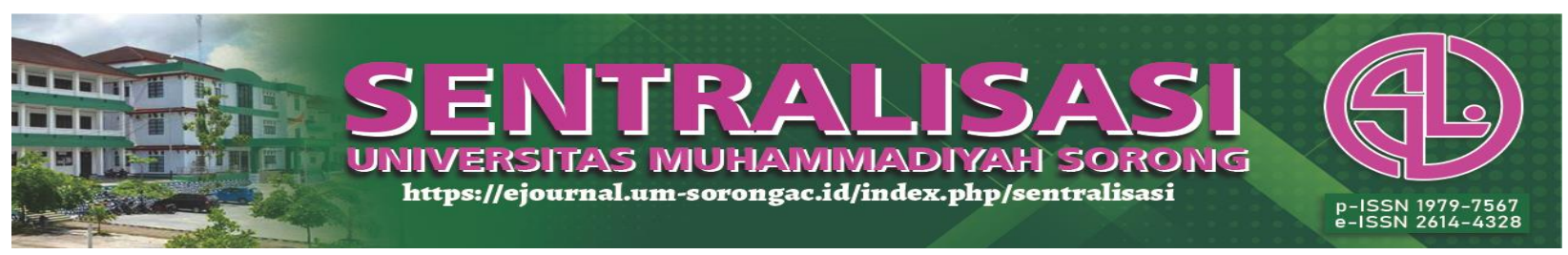

Anova

ANOVA test is an analysis to determine the difference in the value or score of the research variables, which is the respondent's answer before and after the provision of remuneration. The analysis results are presented in the following table.

Table 5. Anova

\begin{tabular}{|c|c|c|c|c|c|c|}
\hline \multicolumn{7}{|c|}{ ANOVA } \\
\hline & & $\begin{array}{l}\text { Sum of } \\
\text { Squares }\end{array}$ & $D f$ & $\begin{array}{l}\text { Mean } \\
\text { Square }\end{array}$ & $F$ & Sig. \\
\hline \multirow{5}{*}{$\begin{array}{l}\text { Performance } \\
\text { Before } \\
\text { Remuneratio } \\
\mathrm{n}\end{array}$} & Between & 86.438 & 11 & 7.858 & 2.676 & .006 \\
\hline & Groups & & & & & \\
\hline & Within & 205.562 & 70 & 2.937 & & \\
\hline & Groups & & & & & \\
\hline & Total & 292.000 & 81 & & & \\
\hline \multirow{5}{*}{$\begin{array}{l}\text { Performance } \\
\text { After } \\
\text { Remuneratio } \\
n\end{array}$} & Between & 72.202 & 11 & 6.564 & 3.193 & .001 \\
\hline & Groups & & & & & \\
\hline & Within & 143.896 & 70 & 2.056 & & \\
\hline & Groups & & & & & \\
\hline & Total & 216.098 & 81 & & & \\
\hline
\end{tabular}

Source: Results of processed data

Based on the table, the $\mathrm{F}_{\text {count }}$ of the performance score before remuneration is 2.676 at the significance level of 0.006 , while the $\mathrm{F}_{\text {count }}$ of the performance after remuneration is 3.193 at the significance level of 0.001 . From these results, it appears that there is a difference in the average performance value before and after the remuneration policy. In this case, employee performance increases after remuneration are provided.

The results indicated that performance allowance or remuneration could improve employee performance. The primary data sources evidence it from respondents that the performance allowance or remuneration, a government program aiming to improve employee welfare, provides positive results in improving employee performance. The improvements include the quality and quantity of work, reliability, accelerated working time, cost savings, service, integrity, work commitment, discipline, and cooperation.

These improvements reflect the government's efforts to improve employee welfare through remuneration programs or performance allowances. As stated in the Regulation of the Minister of Religion of the Republic of Indonesia Number 29 of 2016 concerning the Provision, Addition, and Reduction of Employee Performance Allowances at the Ministry of Religion in article 1 (4), performance allowances are additional salaries for income or remuneration given to civil servants as a form of remuneration as measured according to the criteria for performance evaluation and the success of the implementation of duties and civil servants' performance achievements which are in line with the performance of the organization where the civil servant works. The government's remuneration policy is a planned effort that aims to increase the motivation and value 


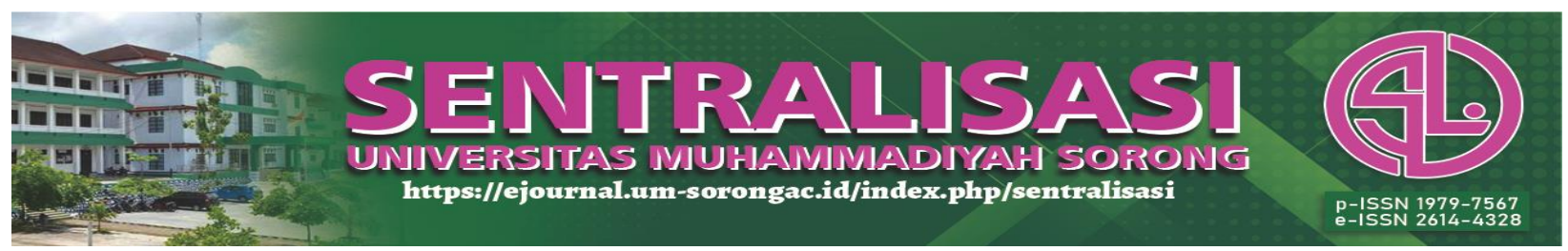

of justice for every employee to be able to compete healthily in increasing maximum performance output and encouraging employees to show more performance that can bring a right image of the organization in society.

The findings of this study are also supported by previous research results (Meilinda et al., 2019) (Nasution et al., 2019) that remuneration positively affects employee performance improvement. In comparison, the research of Istiqomah et al. (2014) found that fairness in the application of remuneration directly did not affect employee performance. However, the effect of remuneration fairness directly on employee performance is mediated through motivation variables. Remuneration can encourage the emergence of new motivation for employees to increase their performance. The research results by N. et al. (2017) also found that remuneration has a significant effect on performance through work satisfaction. These overall results indicate that remuneration can improve employee performance. The government's policy by providing additional income as a reward for performance achievements has provided new energy or enthusiasm for employees, balanced with discipline and quality in service to the community.

The government policy in providing performance allowances or remuneration to employees aims to increase each employee's income and welfare so that they will concentrate more on work and no longer think about deficiencies in meeting their family's needs. The ultimate goal is to provide more services to the community.

\section{Conclusion}

Based on the results of testing and data analysis using the Oneway ANOVA method, it can be concluded that there are significant differences in employee performance before and after the application of remuneration policies by the government to employees of the Ministry of Religion of the Republic of Indonesia. Remuneration is a form of appreciation to employees as a performance allowance, which is expected to improve employee welfare and performance positively. Employee performance improvement can be seen from several indicators: an increase in the quality and quantity of work, reliability, accelerated working time, cost savings, service quality, integrity, work commitment, discipline, and cooperation.

\section{References}

Agama, K. (2016). Peraturan Menteri Agama Republik Indonesia Nomor 29 Tahun 2016 Tentang Pemberian, Penambahan, Dan Pengurangan Tunjangan Kinerja Pegawai Pada Kementerian Agama Republik Indonesia.

Hardani, L., Bachri, A. A., \& Dahniar. (2016). Pengaruh Tunjangan Kinerja Dan Disiplin Kerja Terhadap Kinerja Pegawai Negeri Sipil Balai Karantina Pertanian Kelas I Banjarmasin. Jurnal Wawasan Manajemen, 4(1), 23-37.

Istiqomah, Suharnomo, \& Perdhana, M. S. (2014). Analisis Pengaruh Keadilan Remunerasi Dan Budaya Organisasi Terhadap Kinerja Karyawan Dengan Motivasi Sebagai Variabel 


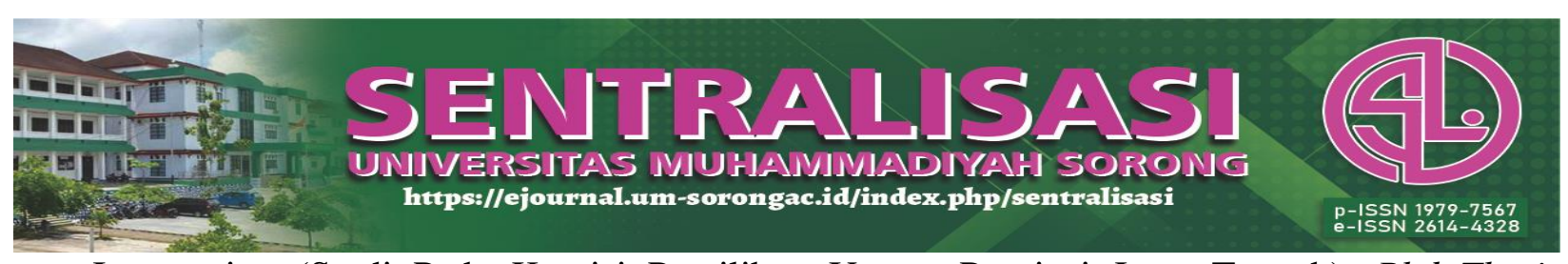

Intervening (Studi Pada Komisi Pemilihan Umum Provinsi Jawa Tengah). Phd Thesis Universitas Dipenogoro, 1-17.

Karim, D. F. (2019). Pengaruh Tunjangan Kinerja Daerah (Tkd) Terhadap Kinerja Pegawai Pada Lingkup Dinas Kelautan Dan Perikanan Kabupaten Banggai. Ilmiah Clean Goverment, 2(2), 189-201.

Meilinda, H., Budianto, A., \& Kader, M. A. (2019). Pengaruh Remunerasi Dan Budaya Kerja Terhadap Kinerja Pegawai (Suatu Studi Pada Balai Besar Wilayah Sungai Citanduy Banjar). Business Management And Entrepreneurship Journal, 1(3), 141-154.

N, A. R., Hendriani, S., \& Efni, Y. (2017). Pengaruh Pendidikan Dan Pelatihan , Remunerasi Dan Budaya Organisasi Terhadap Kepuasan Kerja Dalam Meningkatkan Kinerja Pada Dit Reskrimsus Polda Riau. Psikologi, 13(2), 98-114.

Nasution, H. M., Sudiarti, S., \& Harahap, I. (2019). Pengaruh Remunerasi, Motivasi Dan Kepuasan Kerja Terhadap Kinerja Pegawai Universitas Islam Negeri Sumatera Utara Medan. At-Tawassuth, Iv(1), 66-88.

Saleh, S., \& Darwis, M. (2015). Pengaruh Tunjangan Kinerja Terhadap Kinerja Pegawai Pada Bauk Universitas Negerimakassar. Administrasi Publik, 5(1), 121-130.

Teja, S. G. B. H. (2017). Pengaruh Remunerasi Dan Motivasi Kerja Terhadap Kinerja Karyawan (Studi Kasus Pada Kantor Pengawasan Dan Pelayanan Bea Dan Cukai Surakarta). Daya Saing: Jurnal Ekonomi Manajemen Sumber Daya, 19(2), 109-118.

Usmiar. (2016). Pengaruh Tunjangan Kinerja Terhadap Motivasi Kerja Anggota Polri Dan Pegawai Negeri Sipil Polri Di Lingkungan Negara Republik Indonesia. Menara Ilmu, X(73), $120-127$. 